\title{
A „nőkérdés” tematizálása a politikai pártok diskurzusaiban a forradalom utáni Tunéziában (2011-2014) ${ }^{1}$
}

\author{
NAWEL GHALI ${ }^{2}$
}

\begin{abstract}
ABSZTRAKT
A tunéziai politikai rendszer több mint ötven éven keresztül szekuláris alapokon szerveződött, amely számos jogot biztosított a nők számára. A családpolitika mellett az oktatás, az egészségügy, valamint a gazdasági és politikai szektorok is kedvezően alakultak nemek egyenlösége szempontjából. Ugyanakkor a rendszer autoriter elnyomást gyakorolt minden más politikai erővel szemben. A Ben Ali rezsim 2011. január 14-én történő elsöprése után a tunéziai társadalomnak új gazdasági, társadalmi és politikai kihívásokkal kellett szembenéznie. Az új szekuláris-Iszlám diskurzus vitákat indított, mind a nyilvános, mind pedig a magánszférával kapcsolatban (Zeghal 2013). Ezen viták egyik legégetőbb témája a nők jogainak kérdésköre volt. Az iszlamisták közéleti részvételének következtében az országban új, komplex és az eddiginél kétértelmübb politikai mező jött létre. Ebben a mezőben a nőket - bár a „nőkérdést” eltérő módon tematizálták az egyes politikai szereplők, lényegében a szembenálló és versengő felek egyaránt instrumentalizálták. Ennek a kontextusnak a vizsgálatára a diskurzuselemzés módszerét alkalmazza a kutatás, mely a demokratikus átalakulás alatt zajlott eseményeket, és elhangzott beszédeket elemzi. Célom a forradalom utáni politikai helyzet jobb megértése, annak érdekében, hogy a nők társadalmi és politikai szerepének és lehetőségeinek politikai peremfeltételeit feltárjam Tunéziában.
\end{abstract}

KULCSSZAVAK: diskurzuselemzés, nők reprezentációja a politikai diskurzusokban, forradalom utáni Tunézia

\section{ABSTRACT}

„Women Question” in the Political Parties' Discourse in Post-Revolution Tunisia (2011-2014)

For more than fifty years, the Tunisian political system has been considered as a so-called secular system that had provided women with many rights in education, healthcare and in economic and political sectors, besides that woman friendly family laws reforms After the overthrown of

\footnotetext{
${ }^{1}$ A tanulmány eredetileg angol nyelven íródott, a fordítást Szekulesz Dóra, az ELTE magyar nyelvű Szociológia Doktori Iskola hallgatója végezte. A fordítást lektorálta Dr. Kövér-Van Til Ágnes.

${ }^{2}$ A szerző az ELTE angol nyelvű Szociológia Doktori Iskola hallgatója.
} 


\section{KÖZELKÉP}

Ben Ali regime on 14th of January 2011, the Tunisian society witnessed an economic, social and political significant transformation. A new Islamic-secular discourse have been raised debates both in public and private sphere, women's rights have been one of the incendiary topics of these debates. Therefore, with the participation of the Islamists in political life, the country has faced a new political dynamic which made the pollical scene complex and ambiguous. In this context, discourse analysis is a very important and crucial to be used as a method to approach to the research main question. Some leaders' speeches, events which took place during the democratic transition are examined and analyzed in order to serve the research's analytic interest through the relevant materials.

KEYWORDS: discourse analysis, women representation in political discourse, post-revolution Tunisia

\section{Bevezetés}

Az ország 1956-os függetlenné válása után Tunézia első elnöke, Habib Burgiba szakított a vallásos kormányzással, helyette modern és szekuláris rendszert vezetett be. Az elnök megerősítette az ország kapcsolatait a nyugati világgal (Európa, USA) és visszaszorította az iszlamisták hatalmát. A rezsim kormányzása alatt számos olyan törvény lépett életbe mely a nők jogait erősítette; könnyebbé vált az oktatáshoz való hozzáférés, a politikai és a gazdasági életbe való részvétel, valamint a hozzáférés az egészségügyi ellátáshoz ${ }^{3}$. Az új törvények betiltották a poligámiát, valamint legalizálták az abortuszt, és az örökbefogadást. A burgiba kormány népszerűsítette a nők iskoláztatását ezzel lehetővé téve, hogy a nők a háztartáson kívül is dolgozhassanak, valamint, hogy részt vegyenek a politikai döntéshozatalba, annak érdekében, hogy szerepet vállaljanak a forradalom utáni Tunézia kialakításában. Ezek a reformok emberi és nőjogi szempontból, más arab országok jogrendszerével összehasonlítva, forradalminak számítottak (Grami 2008).

Annak ellenére, hogy a politikai iszlámot betiltották, Burgiba és az ôt követő Ben Ali is számos alkalommal használt vallásos kifejezéseket politikai felszólalásaiban, melynek implicit oka az emberek befolyásolása volt. Ugyanakkor mindkét vezető olyan szekuláris homlokzatot épített, amely korlátozta az iszlamista erőket. Az 1960-as években a fő iszlám politikai pártot az Ennahda Mozgalmat - amely mérsékelt iszlamistaként jellemezte magát -, erőszakosságukra hivatkozva betiltották (Wolf 2017). Sok tagját letartóztatták és megkínozták, sokakat kivégeztek vagy száműztek az országból, a többiek pedig politikai elnyomásban éltek (Cavatorta Merone 2013).

A Ben Ali rezsim 2011. január 14-ei megdöntése után az országban átalakulási folyamatok kezdődtek. Ez új fejezetet nyitott az ország történetében, a régi auto-

\footnotetext{
${ }^{3}$ Családtervezési programok, ingyenes orvosi konzultációk, fogamzásgátló készítmények váltak könynyen elérhetővé.
} 


\section{KÖZELKÉP}

riter rezsimet demokratikus kormányzás kívánta felváltani. Bár az út rögös volt, de Tunézia megkezdte a demokratikus átalakulást, amely politikai, és társadalmi szempontból döntő folyamat kezdete volt. Miután Ben Ali Szaúd-Arábiába menekült, az ország miniszterelnöke, Mohammed Gannúsi ${ }^{4}$ február 27-i lemondása előtt új kormányt alakított, és parlamentáris választásokat hirdetett meg. A szavazáson Bedzsi Kaid esz-Szebszit választották meg az ország ideiglenes miniszterelnökévé. Az előző rezsim alatt tiltott politikai pártokat legalizálták, többek közt a mérsékelt iszlám Ennahda Mozgalmat is, a politikai okok miatt bebörtönzötteket pedig szabadon engedték. A hosszú évekig tartó politikai üldözések után kérdéses volt, hogy mit hoz a jövő az ország zavaros identitását tekintve. Ekkor még senki nem tudhatta biztosan mi lesz az ország sorsa, milyen hatással lesz a politikai iszlám térnyerése a tunéziai társadalomra (Wolf 2017, Zayani 2015). A forradalom után éles viták alakultak ki a nyilvánosságban az iszlamisták, és a magukra szekulárisként tekintők között, amelyek új diskurzusokat teremtettek, ezek többek közt a vallásról, a szekularizmusról, a nők jogairól és a Saría jogról ${ }^{5}$ szóltak (Kammoun 2015). A tanulmány célja, hogy megvizsgálja a forradalom utáni Tunézia (2011-2014) fó diskurzusait, annak érdekében, hogy megmutassa miként formálta a „nő-kérdés” körüli diskurzusokat a két nagy politikai párt vezetője. Rávilágítok arra, hogy a két meghatározó politikai párt miért kezdett el „nő ügyekkel” foglalkozni; megvizsgálom, hogy a háttérben a nők jogainak kiterjesztése iránti valós politika szándék állt, vagy csupán a nők, a „nőkérdés” politikai instrumentalizációjáról beszélhetünk.

\section{Módszertan}

A tanulmány arra tesz kísérletet, hogy elemezze a két fő politikai párt, az Ennahda Mozgalom és a Nidaa Tounés ${ }^{6}$ által létrehozott különféle diskurzusokat ${ }^{7}$ a forradalom utáni Tunéziában (2011-2014). A hangsúly nem csak a politikai beszédek nyelvezetén, szóhasználatán van: a „nyelv, mint konstruáló és konstruált”, hanem „a diskurzus, mint cselekvés" megközelítés is relevanciával bír, amely megteremti a társa-

${ }^{4}$ Tunéziai politikus, Tunézia miniszterelnöke 1999 és 2011 között. 2011. január 14-én a jázminos forradalom hatására lemondó Zín el-Ábidín ben Ali helyére a hatályos alkotmányt megsértve önmagát nevezte ki ideiglenes köztársasági elnöknek, majd fél évvel későbbi időpontra előrehozott parlamenti választásokat írt ki. A tüntető tömeg azonban Gannúsi lépését nem fogadta el, a belföldi és nemzetközi nyomásra helyét Fuád Mebaza, a parlament alsóházának elnöke vette át. Február 27-én Gannúsi kormányfői pozíciójáról is lemondani kényszerült a tiltakozások hatására.

${ }^{5}$ A Saría (arabul: قعيرش) az iszlám erkölcsi, morális vezérelve, az iszlám teológiai rendszerében az Isten által meghatározott helyes viselkedés, szubsztanciális jog. A Saría kiterjed a mindennapi élet valamennyi területére, még a tisztálkodási és étkezési előírásokra is. Legfőbb célja a közösség szabályozása. A Saría vallásjogot örök érvényű isteni kinyilatkoztatás szentesíti, tehát megváltoztathatatlan, csupán értelmezésében van eltérés, mely áganként és kultúránként enyhébb vagy szigorúbb.

${ }^{6}$ Nidaa Tounés (Kiáltás Tunéziáért) világi párt, melyet Bedzsi Kaid esz-Szebszi alapított 2011-ben.

${ }^{7}$ Ayman H (2011) Rasid Gannúcinak, az Ennahda Mozgalom vezetőjének a beszédét tette közzé. 


\section{KÖZELKÉP}

dalmi és politikai gyakorlatokat. Ez a megközelítés hozzásegít ahhoz, hogy megértsük a diskurzusok általános szerkezetét, és azokat a rejtett tartalmakat, amelyek az elemzés által kerülnek felszínre, aminek fontos része, hogy a szövegre, és a beszédre is társadalmi gyakorlatokként tekintsünk (Gill 2000,174). A vizsgált diskurzusok tárgya a „nőkérdés”, amely „a diskurzusok retorikai szerveződésében” és szóhasználatában mutatja meg magát. Nem lehetséges egy diskurzus kezdetét és végét meghatározni, hiszen azok mindig kapcsolódnak újabb és újabb diskurzusokhoz, de kutatási kérdésünk alapján lehatárolhatjuk az elemzendő témát (Wodak 1997). Azt is figyelembe kell vennünk, hogy a tisztán objektív tudományos vizsgálat lehetetlen (Wodak 1989, xvi), mégis a következtetések levonása során, és a vizsgálat alatt megpróbálok törekedni az objektív látásmódra, még ha ez teljesen mértékben nem megvalósítható

Az elemzéshez részleteket válogattam a két fő politikai párt vezetőinek: Rasid Gannúsi (Ennahda Mozgalom párt) és Bedzsi Kaid esz-Szebszi (Nidaa Tounées párt) beszédeiből $1^{8}$, melyeket a parlamenti választási időszakok alatt mondtak el 2011 és 2014 között. A két vezetőnek nagy szerepe volt a politikai mező viszonyainak alakításában. Az egyik jelentős beszédet Rasid Gannúsi mondta a főváros, Tunisz közelében található El Kram városában 2011. október 20-án a tunéziai alkotmányozó gyűlés október 23-ai megválasztása előtt. A beszédet tunéziai dialektussal adta elő. Gannúsi célja elsődlegesen a Ennahda párt jelöltjeinek, és a helyi listavezető Abou Yareeb Marzouki (Verdier 2013) támogatása volt. A kutatás érdekében a beszéd szövegét lefordítottam. A kódolási folyamat alatt a szövegből néhány részletet kiemeltem, és mélyebb elemzésnek vetettem alá. Ezek olyan részek, amelyek a kutatási kérdések szempontjából relevánsak. A másik beszédet Bedzsi Kaid esz-Szebszi adta elő a választási kampány alatt, szeptember 28-án egy főváros közeli észak keleten fekvő városban, Nabeulban. Ez volt az első gyúlés az október 26-ai választások elött, aminek az volt a célja, hogy bemutassa a Nidaa Tounés listáján induló jelölteket (Alchourouk 2014). A beszédet tunéziai dialektusban mondta el. A vizsgálat, és az elemzés céljából ezt a beszédet is lefordítottam, majd a kódolás után kiválasztottam a téma, és a kutatási kérdés szempontjából releváns részeket.

A beszédek vizsgálata azért fontos, mert egyfelől azokban világosan megjelenik a nők sztereotip, a sajátos tunéziai gender rezsimet jellemző politikai reprezentációja, másfelől azért, mert ezek aktív konstruálói a nőkkel kapcsolatos társadalmi szemléletnek és gyakorlatoknak.

Az elemzés alapjául a Wodak (1989) által összefoglalt, Bertold Brecht által felvetett kérdések fognak szolgálni. A kérdések a következők: Mi a beszélő szándéka/ mit akar mondani? Mely mondatok világítják meg leginkább a beszélő szándékát, és

${ }^{8}$ A vizsgált időszakban e két politikus volt a legismertebb és legközkedveltebb, továbbá politikailag alapvetően meghatározó személyiség Tunéziában. 


\section{KÖZELKÉP}

annak a már általam értelmezett jelentését? Ennek megfelelően, a fókusz a kontextuson van, nem a hagyományos „a mondat, mint legnagyobb egység” megközelítésen. Erre azért van szükség, hogy jobban megértsük a „beszéd aktusokat”, a „kontextust”, „az illokúciós és perlokúciós aktusokat” de legfőképpen a diskurzusban megmutatkozó hatalmat: azaz azt, hogy ki beszélhet?, kinél van a kontroll? ki választ?, ki határozza meg mi a jó és mi a rossz viselkedés? (Wodak 1989, xiv). A választások alatt előadott beszédek kiemelkedően fontosak, hiszen hozzásegítenek ahhoz, hogy megértsük a pártok célját, és a nőkkel kapcsolatos törekvéseiket, és választ kaphatunk arra, hogy hogyan történik és milyen szerepet tölt be a „nőkérdés” tematizálása az adott politikai mezőben.

\section{Mi a diskurzus?}

A diskurzus egyfajta „közös tudás” (common currency), különféle tudományterületek által elsajátított fogalom, főként a szociológiában, nyelvészetben, filozófiában, pszichológiában használják, de más diszciplínákban is előfordul. A fogalmat sokszor a jelentésének meghatározása nélkül alkalmazzák, mivel úgy vélik azt mindenki ismeri. A diskurzus jelentése gyakran az irodalmi, és nem irodalmi szövegek elemzésére korlátozódik, az elméleti használata általában kibővíti, és bonyolítja a szó tartalmát: ennek ellenére rengeteg írás született, ami megpróbálja definiálni a diskurzus szó jelentését (Mills 1997, 4).

Michel Foucault definíciója inkább kitágítja a diskurzus szó „ingadozó jelentését”: „néha az összes állítás általános tartományaként, néha az állítások individualizálható csoportjaként, néha pedig szabályozott gyakorlatként kezelem, amely számos nyilatkozatot tartalmaz." (Foucault 1972, 80) A meghatározás utolsó elemében Foucault-t kevésbé érdeklik a tényleges megszólalások/szövegek, mint az egyes megszólalásokat és szövegeket előállító szabályok és struktúrák. A diskurzusnak ez a szabály által vezérelt jellege az elsődleges fontosságú számára (Mills 1997). Legismertebb elmélete szerint, Foucault a diskurzust a hatalom kifejeződéseként értelmezi, ahogy azt $A$ diskurzus rendjében írja: „A diskurzus nemcsak egyszerűen tolmácsolja a küzdelmeket és az uralmi rendszereket, hanem érte folyik a harc, általa dúl a küzdelem; tehát a diskurzus az a hatalom, amelyet az emberek igyekeznek megkaparintani." (Foucault 1998, 51) Jól jellemzi ez a meghatározás a tunéziai politikai diskurzusokat.

A „nőkérdésről” szóló diskurzusok akkor keletkeztek, amikor a bizonytalanság homálya még elrejtette az új politikai irányvonalat, és a helyzet törékeny és összetett volt. Az ország megosztottsággal nézett szembe, mert a politikai mezőben harc dúlt a szekuláris és az iszlamista erők között, s ez a harc rányomta bélyegét a nőkről szóló 


\section{KÖZELKÉP}

diskurzusokra is. Domenica Preysing9 szerint „Tunézia rögös úton jár mióta megkezdődött az „átmenet” a Ben Ali rezsim és az új államrend között. Az út egyértelműen demokratikusabb irányba visz, de a változás megosztó és erős politikai verseny folyik" (Preysing 2016, 15). A politikai ellenfelek csatározása miatt az átalakulást nagyon nehéz volt végrehajtani (Daniele 2014). A kiélezett politikai térben a versengő felek szélsőséges megfogalmazásokkal igyekeztek megragadni a diskurzus feletti kontrollt és ezáltal a kizárólagos hatalmat. Például az önmagukat szekulárisként meghatározók az Ennahda párt iszlamista tagjait a „modern tunéziai társadalom kívülállóiként" bélyegezték meg, az iszlamisták pedig istenkáromlással vádolták a szekulárisokat, akik nem tartoznak az Arab-Iszlám világba (Preysing 2016).

Mivel a 2011-es forradalom spontán népmozgalom formájában valósult meg, ezért nem köthető semmilyen vezetőhöz, és nem követte kidolgozott politikai program sem. A forradalom után különféle politikai csoportokhoz tartozó aktorok jelentek meg, akik az ország jövőjéről gondolkozva számos diskurzust hoztak létre. Például a Ennahda párt által generált diskurzusok főleg a Saría törvénnyel voltak kapcsolatosak, melyek rendszeresen azzal végződtek, hogy a muszlim nők identitásáról, öltözködéséről, testéről - beleértve a hidzsábot (fejkendő), vagy a nikábot (arcot eltakaró kendő) - és a váláshoz, a poligámiához vagy az abortuszhoz kapcsolódó viszonyukról vitatkoztak (Kammoun 2015). A „nőkérdés” tehát újra aktuálissá vált ebben az instabil időszakban. A „nőkérdés” kifejezést a tunéziai kultúrában és közbeszédben évszázadok óta használják. Egy olyan átfogó fogalomról van szó, amely minden olyan problémát felölel, amely a nőket, mint társadalmi csoportot érinti, ezek közé tartoznak például a jogi egyenlőtlenség kérdései, az elnyomás és a nők elleni erőszak a különböző formái, a nemek közötti családon belüli (és kívüli) egyenlőtlen hatalmi viszonyok, a munkamegosztás nemek szerinti rendje, a nők társadalmi életben való részvételének kérdései stb. Ezeket a problémákat célozzák a nőjogi, illetve feminista törekvések (Vogel 1995), melyek már a 20. század 1930-as éveitől jelen voltak Tunéziában. A „nőkérdés” különböző elemei a kelet-nyugat, tradicionális-modern binaritás kategóriáiban jelentek meg, amely egyfajta diszkurzív konfliktushoz és következésképp kiélezett küzdelemhez vezetett a politikai térben (Grami 2018).

Jól tudjuk, hogy minden társadalomban a diskurzusokat azok dominálják, akik létrehozták azokat, és olyan folyamatokat generálnak, amelyek célja, hogy ellenőrzésük alatt tartsák az eseményeket, a hatalom megszerzése és megtartása érdekében. Ezért folyamatosan és következetesen alkalmazzák a legkülönfélébb diskurzus ritkítási eljárásokat (Foucault 1998). A társadalom legelterjedtebb diskurzus szúkítési eljárásai (Foucault 1998) a kizárással és a tiltással vannak kapcsolatban. A po-

\footnotetext{
${ }^{9}$ Közismert kutató és szerző, akinek „Transitional Justice in pos-revolutionary (2011-2013): How the past shapes the future” című könyve nagy hatást gyakorolt a tunéziai közvéleményre.
} 


\section{KÖZELKÉP}

litikai pozíciók nemi alapú elosztásának diskurzusa a nők kizárását eredményezi, amely rávilágít a hatalomgyakorlás maszkulin természetére, ahol a kontroll egyik eszköze az un. diszciplína ${ }^{10}$. Itt nem az igazság számít, vagy bizonyos csoportok érdekeinek hiteles képviselete, hanem az alkalmazott módszerek és a terminológia, melyet a már pozícióban lévők határoznak meg, ezzel keretet és mozgásteret szabva a diskurzusba belépőknek, megszólalóknak. A diskurzusban a beszélő és a befogadó közti viszony nem egyenlő, nem reciprocitáson alapul. A diskurzus a gondolatok közötti intervallum, amelyet nyelvre (szavakra) fordítanak, hogy olyan beszédet alkossanak, amelynek sajátos jelentése és hatása van (Foucault 1970), s amellyel a befogadó cselekvését lehet befolyásolni. Az itt következő elemzések azt kívánják kibontani, hogy mi az a mód ahogyan megkonstruálják politikai mondanivalójukat a szövegek előadói és milyen szerepet szánnak mindebben a nőknek, valamint azt, hogy mi az az illokúciós szándék és perlokúciós hatás, amit a nyílt vagy rejtett formában elérni kívánnak.

\section{Rasid Gannúsi beszédének elemzése (2011. október 20.)}

Az Ennahda párt alapítója és vezetője, Gannúsi beszédének egyik fő vonulata az, amikor azt javasolja, írjanak ki népszavazást a Személyiségi Jogokról szóló Törvényről ${ }^{11}$, annak érdekében, hogy újratárgyalják az abban megtiltott olyan gyakorlatokat, mint a poligámia, és módosítsák az adoptálásról szóló törvényt, amely ellentmond a Saría jognak. Nem ő követeli nyíltan a Saría jog bevezetését, hanem „egyes párttagok" javaslataként tünteti fel azt, akik annak érdekében kívánják ezt, hogy a tunéziai társadalom az iszlamizálódás útjára lépjen (Grami 2018). Majd ezt követően az Iszlám olyan meghatározását adja a beszédben, amely magába foglalja a Saría jogot: „Az Iszlám, Ibn al Qayyim szerint: hol igazságosság van, ott van a jólét, a szabadság és az igazság, ott van az Iszlám, ott van a Saría jog." (Gannúsi 2011) A fentiek alapján egyértelmű, hogy Gannúsi szerint az Iszlámot csak az 'igazságosság', 'jólét', 'szabadság', 'igazság' és a Saría jog fogalmai mentén érthetjük meg. Különösen érdekes elgondolkodni a 'szabadság' szó értelmezésén. Az Oxford szótár szabadság definíciója szerint az az: „Arra való képesség, vagy jog, hogy valaki úgy cselekedjen, beszéljen, gondolkodjon, ahogy szeretne"12. Ennek a definíciónak az értelmében a Saría jog nem jelenthet szabadságot, mivel annak törvényei szerint a nők nem cselekedhetnek szabadon. Éppen ennyire érdekes megvizsgálni az Iszlám 'igazságosság' fogalmát az egyedül álló nőkről folyó politikai és társadalmi diskurzus háttere előtt. Az Ennahda Mozgalom 2011-es választási győzelme után a párt egyik képviselője, Souad Abdera-

\footnotetext{
${ }^{10}$ Foucault a diszciplínát (nem a tartalmi, hanem a formai követelményeken van a hangsúly) a diskurzus ritkítás egyik eljárásának tekintette.

${ }^{11}$ Personal Status Code.

${ }^{12}$ Oxford Online Dictionary, 2019. https://www.lexico.com/definition/freedom
} 


\section{KÖZELKÉP}

him - aki a nyilvánosság szemében a mérsékeltebb politikai iszlámot képviselte, mivel nőként nem viselt fejkendőt -, beszédet tartott az alkotmányozó gyűlésen a Ben Ali által vezetett autoriter rezsimről, amelyben hangot adott az egyedülálló anyákról ${ }^{13}$ alkotott véleményének, valamint bírálta a liberális feministákat, akik az egyedülálló anyákat védő törvény bevezetéséért lobbiztak. Abderahim többek közt azt javasolta, hogy a házasságon kívül született gyerekeknek is biztosítsanak szociális jogokat, azonban az anyákat ne kezeljék egyenlően a házasságban élő nőkkel. A beszédben kiemelte, hogy „nem akarjuk normalizálni a házasságon kívüli gyermekvállalást" (Grami 2018, 39). Később egy helyi rádióadásban megkérdezték tőle, hogy mit gondol a tunéziai egyedülálló nők helyzetéről, amire így válaszolt: „Szégyen erről a témáról egy arab-muszlim társadalomban beszélni. Nem kéne olyan törvényekért lobbiznunk, amelyek megvédik az egyedülálló anyákat, ehelyett inkább arra kéne eszközt találnunk, hogy felügyeljük a morális értékeiket. Nem kéne arra buzdítani őket, hogy bűnbe essenek... és nem kéne jogokat biztosítani nekik." (Tuniscope 2011)

A kinyilatkoztatás, úgy értelmezhető, hogy Abderahim szerint a nők nem hozhatnak szabad döntést olyan kérdésekben, amelyek ellenkeznek a Saría jog rendelkezéseivel, azaz, ha nem engedelmeskednek a tradicionális törvényeknek, akkor társadalmi kiközösítéssel kell szembenézniük. Eszerint a női jogok kiterjesztése nem szükséges, hiszen a nők feladata az engedelmesség, az alávetettség elfogadása, és a férfiak kiegészítése. Abderahim egyedülálló anyákról alkotott véleménye sok feministát, és emberi jogi aktivistát felháborított (Tuniscope 2011). Mindebből jól kiviláglik az Iszlám „igazságosság” fogalma. Mindeközben az Ennahda párt úgy állította be a szekuláris feminista aktivistákat, akik egyenlő jogokat követeltek minden nő számára, mint hitetleneket, akik a nyugatról importált gondolatokkal és elképzelésekkel próbálják a tunéziai nőket elrettenteni muszlim identitásuktól. A párt támogatói a muszlim társadalom ellenségeiként tekintettek rájuk, a Bourgiba, és a Ben Ali rendszer alatt működő két feminista szervezetet pedig a diktatúra részeként, és az iszlám ellenségeként jellemezték (Grami 2018).

Abderahim nyilatkozata ugyanakkor felidézi, a világ számos országában megtalálható női politikusnak azon retorikáját, amely maszkulin nézőpontokat támogat. Az európai országokban is egyre inkább előfordul az olyan, a nők által is nyilvánosan képviselt beszédmód és diskurzus, amely tradicionális ideológiákra épül, feminizmus ellenes, tagadja a társadalmi nemek létezését, és valamilyen formában a női egyenlőség és a női jogok ellen irányul. A 2010-es évek elején inkább csak az európai szélsőjobboldali pártok női képviselőinek retorikájában jelenik ${ }^{14}$ meg ez a beszédmód, majd az ezt követő években egyre inkább beszivárog a konzervatív politikusok diskurzusaiba és manifesztálódik politikájukban is. Az „anti-gender” diskurzus

${ }^{13}$ Ez ebben a kontextusban kizárólag azokat a nőket jelenti, akik házasságon kívül vállalnak gyereket.

${ }^{14} \mathrm{Pl}$. Marine Le Pen retorikája a 2012-es francia választások során. 


\section{KÖZELKÉP}

kedvenc témái itt is a „megfelelő” anyaság ${ }^{15}$, a gyermekvállalás elsődlegessége, valamint a férfiak társadalomformáló, produktív, míg a nők reproduktív szerepeinek hangsúlyozása (Pető és Kováts, 2017). A patriarchális nézőponttal azonosuló beszédek hangzottak el például a magyar Parlamentben is jó néhányszor női képviselők részéről, különböző témákban. Ilyen volt például „a házasságon belül legálisnak tekintett nemi erőszak" kriminalizálásával és a női „kvótarendszer” bevezetésével kapcsolatos vita. 1997-ben egy magyar jogász parlamenti képviselőnő a büntetőtörvénykönyv módosítása kapcsán, amely a házasságon belül elkövetett nemi erőszak legalitásának eltörlését célozta, kijelentette, hogy: „ez a rendelkezés (a házasságon belül elkövetett nemi erőszak megbüntetése) túlhatalmat jelent a házasságban élő nők számára, akik visszaélhetnek ezzel a hatalommal, és hamisan tanúskodnak majd férjük ellen". Hasonló jegyeket visel azoknak a női képviselőknek az érvelése 2007ben és 2010-ben, akik kijelentették, hogy nem akarnak „kvótanők” lenni és ezzel szembeszálltak a képviselőtársaik által előterjesztett női kvótarendszerre vonatkozó törvényjavaslattal (Kövér, 2015, 9-14).

Visszatérve az elemzés tárgyát képező Gannúsi beszédhez, ebből tisztán kirajzolódik, hogy a pártvezető elvei szerint az Iszlám, és a Saría jog összekapcsolódik. Ezt az a tény is bizonyítja, hogy az Iszlám meghatározásához egy szunnita imámra, Ibn al Qayyimra hivatkozik, aki Damaszkuszban született a 11. században. Qayyimra az ortodox szunnita jogtudomány Hanbali iskolájának ${ }^{16}$ képviselője, amely irányzat a Koránon, és a szunnita hagyományokon alapuló fikh jogfilozófiát használja az Iszlám értelmezéséhez (Abdeladhim 1984). Azonban a tunéziai muszlimok többségében az Iszlám Maliki iskoláját ${ }^{17}$ követik (Mighahed - Lack 2013). Az Iszlám szunnita irányzatában négy nagy iskola van, amelyek némiképp eltérően vélekednek a rokonsággal, családdal és nőkkel kapcsolatos jogi szabályozásokról (Charrad, 2011). Gannúsi beszéde azzal, hogy a Hanbali iskolára hivatkozott, implicit módon ráerősített arra, hogy az Ennahda párt más arab országokból importál, a tunéziai hagyománytól eltérő gondolatokat az Iszlámról, és a Saría jogról. Összességében azt mondhatjuk, hogy Gannúsi beszéde értelmezhető az Ennahda párt törekvéseként arra, hogy a Sariát

\footnotetext{
${ }^{15}$ Itt elsősorban a házasság fontossága és az egyedülálló nőként való gyermekvállalás elutasítása tematizálódik.

${ }^{16} \mathrm{~A}$ hanbaliták szöveghűségükről és dogmatikus érvelésükről ismertek, az iszlám törvényének forrásaként kizárólag a Koránt és a szunnát ismerik el. Rítus dolgában a legszigorúbb, a modern újításokkal (bidaa) szemben a legkevésbé toleráns madzhab. A szunnita iszlám legkonzervatívabb jogi iskolája, amely csak a szunniták mintegy öt százalékát teszi ki. Ezzel szemben erős befolyást gyakorolnak az egész szunnita közösségre. (Abeladhim C 1984)

${ }^{17}$ A Tunéziában uralkodó Maliki iskola a többi szunnita jogi iskolától elsősorban azokban a forrásokban különbözik, amelyeket a szabályainak a levezetésére használ. Mint a Saría összes szunnita iskolája, a Maliki iskola is a Koránt használja elsődleges forrásként, amelyet Mohamed mondatai, szokásai/hagyományai és gyakorlata követ. A Mālikī iskolában az említett hagyomány nemcsak a hadíszokban (gyakorlati életre vonatkozó mohamedi tanítások) rögzítetteket foglalja magában, hanem a négy helyesen vezetett kalifátus jogi döntéseit is, továbbá az iskola elfogadja a kötelező konszenzust és az analóg érvelést a szunnita jogtudósok többségével együtt. (Abeladhim C 1984)
} 


\section{KÖZELKÉP}

ne a Maliki, hanem a Hanbali hagyomány Korán és szunna értelmezése alapján alkalmazzák, mely iskola jóval dogmatikusabb és konzervatívabb, mint a Tunéziában uralkodó Maliki hagyomány.

Ugyanebben a beszédben a pártvezér többször utal az Ennahda párttagok traumatikus élményeire, amelyeket a Ben Ali vezetés alatt kellett elszenvedniük: „Észrevettem, hogy minden benzinkúton, ahol megálltunk emberek gyűltek körénk. Ők Tunézia gyermekei, a Ennahda fiai és lányai. Az az igazság, hogy ott voltatok 1989 óta, csak az autoriter rendszer manipulált titeket, és ez katasztrófához vezetett. A húsz éven át tartó katasztrófa oka pedig az 1989-es választások elcsalása volt. Ezúttal nem engedjük, hogy ez a szomorú eset megismétlődjön. Nem engedjük, hogy meghamisítsátok egy generáció álmait, egy generációét, amely meghalt volna azért, hogy szabad parlamentet teremtsen, amely garantálja, minden embernek az egész országban, hogy a szabad Tunéziában csak Istentől kelljen félnie. Nem engedjük, hogy újra manipuláljátok az embereket. Ötven év elég volt, ötven év manipuláció elég volt." (Gannúsi 2011)

A 2011-es októberi választási kampány alatt, az Ennahda párt interjúkat és dokumentumokat mutatott be a forradalom előtt elnyomott hidzsábot viselő nőkről, hogy felhívja a tunéziaiak figyelmét az előző rezsim igazságtalanságaira, ezzel további szavazatokat szerezve a pártnak (Grami 2018). Beszédében Gannúsi megpróbált emlékeztetni az elnyomással és üldöztetéssel teli múltra. 1989-ben, miután az Ennahda megvádolta a Ben Ali kormányt a választási szavazatok manipulálásával, sok párttagot bebörtönöztek és megkínoztak, másokat kivégeztek, vagy, ahogy Gannúsit is, elüldöztek az országból (Louden 2015). A szövegben katasztrófaként vagy szomorú esetként hivatkozik ezekre a traumatikus emlékekre, ezzel arra akarja késztetni a választókat, hogy szavazatukkal nyilvánítsanak szimpátiát a korábban elnyomottak irányába. Olyan kifejezéseket ismételt, mint 'manipulálni', 'manipuláció', 'nem engedjük' - ezt háromszor is -, 'félelem nélkül', és kétszer elhangzott az 'ötven év elég volt' mondat. Az ismétlést arra használja, hogy megerősítse a mondanivalóját. A 'nem engedjük' kifejezés implicit tartalma az lehet, hogy erőszakot fognak alkalmazni, ha elveszítik a választást. Ebben az esetben az emlékezetpolitika manipulatív eszközként jelenik meg, amit a szavazók befolyásolására használnak. Ahelyett, hogy az előző rezsim jó intézkedéseit megemlítené, mint a modernizáció vagy a társadalmi fejlődés, inkább a rossz emlékeket, mint az elnyomás, és kizárás helyezi a középpontba.

Az 1989-es választásokat az Ennahda elvesztette, és a beszéd arra utal, hogy nem akarja, hogy a 2011-es választásokon is alulmaradjon. Ha ez mégis megtörténne, ez a választási csalás gyanúját veti fel hiszen, a szöveg alapján, „minden tunéziai ember a pártot támogatja”. Ezt a következő szövegrésszel támasztja alá: „Ők Tunézia gyermekei, az Ennahda fiai és lányai. Az az igazság, hogy ott voltatok 1989 óta." (Gannúsi 2011) 


\section{KÖZELKÉP}

Diskurzusai alapján az Ennahda Isten pártjaként azonosítja magát, így akik őket támogatják, közelebb kerülnek az Istenhez, az isteni akarathoz. Gannúsi így fogalmaz beszédében: „Arra kérjük Istent, hogy teljesítse be az emberek kéréseit, arra kérjük, hogy adja meg a felhatalmazást, hogy szolgáljuk őt, és a népet." (Gannúsi 2011) Ebben a mondatban az Ennahda az Isten által kijelölt pártként tünteti fel magát, a pártként, mely közvetítő Isten és az emberek között. Azaz a párt van legközelebb Istenhez, és csak ők képesek arra, hogy az emberek akaratát közvetítsék Istennek. „Arra kérjük Istent, hogy teljesítse az emberek kéréseit/elvárásait”. Ehhez kapcsolódóan a 'felhatalmazás' kifejezés használata egyfajta gyámságot vagy gondnokságot jelent a tunéziai muszlimok felett. Gannúsi beszéde így folytatódik: „Az Ennahda háza tágas, befogad minden tunéziait, befogadta a legnagyobb arab filozófust Abou Yaraabot, egy ház, ami elég tág ahhoz, hogy befogadja Sauad Abrehaimot, a ház, ami elég tág ahhoz, hogy minden tunéziai nőt befogadjon. Megmondtuk a más mozgalmakban résztvevő szövetségeseinknek, hogy ezek az emberek a mi vezetőink, és képviselőink. Mutassátok be vezetőiteket, válasszatok egy fátylat viselő nőt a listátok elejére! Az Ennahda háza elég tág ahhoz, hogy befogadjon minden őszinte tunéziai embert, attól függetlenül, hogy visel-e fátylat vagy sem. A történelem, és az igazságosság függvényében az Ennahda elfogulatlanul, a legalkalmasabb jelölt. Az őt körül vevők nem a véletlen folytán kerültek oda, hanem intelligens emberek tudatos, és szabad döntése következtében. Arra kérjük Istent, hogy teljesítse be az emberek akaratát, annak érdekében, hogy képesek legyünk élni a felhatalmazással, így szolgálva Istent és az embereket." (Gannúsi 2011)

Gannúsi a „ház” analógiát használja, amely a családi élet zárt terének szimbóluma. Így fogalmaz: „A Ennahda háza tágas, befogad minden tunéziait, befogadta a legnagyobb arab filozófust Abou Yaraabot, egy ház, ami elég tág ahhoz, hogy befogadja Sauad Abrehaimot, a ház, ami elég tág ahhoz, hogy minden tunéziai nőt befogadjon." (Gannúsi 2011) Sauad Abderahim egy gyógyszerész, fátylat nem viselő nő, Abou Yareeb Marzouki pedig egy filozófus, akit a „modern Iszlám” képviselőjeként tartanak számon (Verider 2013). Azzal, hogy Gannúsi őket emelte ki, bizonyítani kívánta, hogy az Ennahda befogadja ezeket az embereket, vagyis az említett ház „vendégei” lesznek. Ez alapján, engedelmeskedniük kell a „házigazdának”, de nem képviselik a párt ideológiáját, mivel csak „vendégek”, nem tartoznak a „családhoz”. A lista elejére helyezés, úgy is értelmezhető, hogy bár a „vendégek” tiszteletbeli pozíciót kapnak, de ez annak érdekében történik, hogy a ház „homlokzatán” a sokféle választás lehetősége díszelegjen. A „vendégek” irányába mutatott nagylelkűség látszatával, több szavazatot kívántak szerezni, és le akarták mosni magukról, az ellenfeleik által hangsúlyozott konzervativizmus, és erőszak vádját. Azzal, hogy Souad Abderhaimot fátylat nem viselő nőként mutatta be, az öltözködésére (testére) helyezte a hangsúlyt, nem pedig képességeire és a tanult nő megbecsült társadalmi státuszára. Ezzel szemben nem felejtette el Abou Yareb Marzouikot filozófusként meghatározni. Gannúsi a női párttagokról csak a beszéde végén ejtett szót, ráadásul nem is azokról, 


\section{KÖZELKÉP}

akik a „családhoz tartoznak”, hanem a párt „vendégeiről”. Ugyanakkor az, hogy token vagy „dísznőket” helyeznek a választási listák élére nem ismeretlen a világban, különösen a demokratikus átmenetek idején gyakran tapasztalható ez a jelenség, ahogyan ezt a nepáli, a bolíviai és a dél-afrikai tapasztalatok is mutatják (Brechnmacher - Hubbard 2020).

Gannúsi sok könyvében és cikkében foglalkozik az állam és a vallás kapcsolatával, a legtöbb esetben a szekularizmus fogalmát tendenciózusan összekapcsolja az autoritarianizmussal, azzal a céllal, hogy a szekularizmust diszkreditálja. Írásaiban elmondja, nem elég, ha az Iszlám nincs állami elnyomás alatt; az államnak nem szabad semlegesnek lennie a vallással kapcsolatban, épp ellenkezőleg, az államnak kell az Iszlám végrehajtójának lennie. Fontos, hogy Gannúsi nem említi a „Saría végrehajtás” kifejezést, helyette az „Iszlám végrehajtást” használja. Ez egy új fogalom, aminek a jelentését eddig nem tisztázta. Mindezt megfontolva kijelenthetjük, hogy a Gannúsi beszédében nem a párt ideológiáját tükröző példákat mutat be, ezeket inkább elrejti és a befogadás képviselőjeként prezentálja pártját, amely tolerál különféle életformákat. Ezen belül a nőkkel annyiban foglalkozik, amennyiben kiemeli az olyan testi gyakorlatokat, mint a nők öltözködése (Zegal 2013).

\section{Bedzsi Kaid esz-Szebszi beszédének elemzése (2014. szeptember 28.)}

Ahogy már említettem, a Nidaa Tounés 2012-ben lépett be a tunéziai politikai életbe. Ennek okán a párt először 2014 októberében szerepelt először parlamenti választásokon.

Bedzsi Kaid esz-Szebszi még a közönség köszöntése előtt humoros stílusban, így kezdte beszédét: „a nők elől vannak, a férfiak pedig hátul, hogy lehet ez?”18 (esz-Szebszi 2014). Ezzel a viccel Bedzsi Kaid esz-Szebszi azt próbálta éreztetni, hogy a pártnak olyannyira fontos a nők helyzete, hogy előtérbe helyezi őket, fontosabb pozícióba, mint a férfiakat, még akkor is, ha ez a tunéziai társadalomban nem elfogadott. Azt kérdezi, „hogy lehet ez”, mert biztos abban, hogy ezt a kérdést felvetik. Ennek elkerülésére világos választ ad: „azt kell mondanom, hogy tőlük függ a választások sikere” (esz-Szebszi 2014). Ebben az összefüggésben, teljesen átláthatóvá válik, hogy a párt célja az, hogy a nőket „liftként” használva több szavazatot szerezzen a választásokon. A beszédet így folytatta: „Miért szeretjük őket? Azért, mert ők a sikerünk legalapvetőbb biztosítékai, nem esztétikai oka van annak, hogy egy nő áll itt (elől), egy férfi pedig ott (hátul), nem emiatt van, hanem azért, mert ettől leszünk sikeresek" (esz-Szebszi 2014). A mondatnak implicit és explicit jelentései is vannak. Egyfelől nyíltan kimondta, hogy a párt nem esztétikai, hanem pragmatikus célból, eszközként

${ }^{18}$ Ezzel a beszédet mondó arra utal, hogy a színpadon a párt jelöltjeit úgy állították fel, hogy a nők elől a férfiak pedig hátul voltak. 


\section{KÖZELKÉP}

használja a nőket: a szavazatok elnyerése érdekében. Másfelől, implicite a szöveg a nőket a külsővel hozta összefüggésbe (esztétikai okok), azaz, azt hangsúlyozta, hogy a külső fontosabb, mint a belső, vagy a kompetencia.

Ezután a politikai élet jellemzésébe kezdett: „Két lehetőségünk van: vagy ugyanebben a helyzetben maradunk, azaz visszafelé megyünk az időben, ahogyan ezt az utóbbi három évben tettük, amikor ötven évet mentünk vissza, vagy a fejlődés és a jólét felé vezető utat kezdjük el járni, hogy olyanná váljunk, mint a fejlett országok. Nem az a célunk, hogy új országot építsünk, hanem az, hogy az ötven évvel ezelötti országunkat visszaállítsuk, amelynek az emlékét az elmúlt években tönkretették" (esz-Szebszi 2014).

Nyíltan kijelenti, hogy két szemben álló lehetőség van. Azt mondja, hogy az egyik lehetőség hátrafelé tart. A 'hátrafelé' kifejezés arra utal, hogy valami ódivatú, zárt, konzervatív, írástudatlan, amivel egyértelműen az Ennahda pártra céloz. Így fogalmaz: „az utóbbi három évben ötven évet mentünk vissza ” (esz-Szebszi 2014), ezzel az iszlamisták 2011-es forradalom utáni politikai feltűnésére utal. Ezzel szemben a másik lehetőség, ami a Nidaa Tounés pártot jelenti, a haladást, és a jólétet szimbolizálja. Azzal, hogy azt mondja, „Nem az a célunk, hogy új országot építsünk, hanem az, hogy az ötven évvel ezelőtti országunkat visszaállítsuk" azt akarja tudatni, hogy a párt megörökölte a „burgibai ideológiát” az iskolázottság fontosságáról, a nők felszabadításáról, és az egyenlő jogokról. Később megemlíti, hogy „Ez a program már a függetlenség óta létezik. Először is, ez népszerűsítette az oktatást, és felszabadította a nőket, látják mennyi nő van itt (rámutat egy nőre, aki mögötte áll) azelőtt egy nőt sem láttak az utcán" (esz-Szebszi 2014). Ezzel azt tudatja, hogy a gyarmati időkben, és azelőtt, a nőknek otthon kellett maradnia, elsődleges feladatuk a házimunka elvégzése, a gyerekek felügyelete, és férjük igényeinek kielégítése volt, tilos volt az otthonon kívül munkát vállalniuk. A függetlenség óta viszont a Burgiba által végrehajtott társadalmi, gazdasági, és politikai reformok következtében a nők helyzete megváltozott.

A beszédet így folytatta: „A mozgalmunk reformista alapokon nyugszik, amely Kheireddine Bechával kezdődött, és Habib Burgivával folytatódott, ezután pedig mi jövünk. Mi vagyunk a következő generáció. 2012 március 24-én, volt egy találkozónk Monasztirban, Bourgiba városában, onnan kezdtük el”. Hozzátette: „Felkészülünk: amikor tudatosítjuk az embereket, amikor felszabadítjuk a nőket, amikor hozzáférhetővé tesszük az egészségügyi szolgáltatásokat, ez a felkészülés a demokratikus államformára" (esz-Szeszbi 2014). Itt emlékeztet arra, hogy a pártja az általa reformistáknak tekintett áramlathoz tartozik, ami Habib Bourgibához köthető. Az ismétlés, azt a célt szolgálja, hogy megerősítse, és emlékeztesse a párt politikai hátterét.

Esz-Szebszi a civil társadalomról is beszélt: „Üdvözlöm a civil társadalmat, ez egy olyan fejlemény, amire azelőtt nem volt példa. Azt a civil társadalmat, ami nem akarja bevezetni a Saría jogot, és azokat, akik egyenlőséget szeretnének férfiak és nők között" (esz-Szebszi 2014). Ebben a szakaszban esz-Szebszi a civil nőmozga- 


\section{KÖZELKÉP}

lomra utal, amely jelentősen megerősödött 2011 után. Ezt a kijelentést továbbá arra is használta, hogy emlékeztesse a közönséget a nemek közötti egyenlőséggel foglalkozó 28-as cikkelyre ${ }^{19}$. Az alkotmányozás során 2011-ben, amikor az Ennahda párt volt hatalmon, egy olyan új cikkelyt fogadtak el, ami szerint a nők csupán kiegészítői a férfiaknak. A törvény az Ennahda párt többségi szavazatával lépett hatályba. A civil társadalom ellenállása eredményeként a törvényt megváltoztatták, és az új szöveg a férfiak és nők egyenlőségét fogalmazza meg (Charrad - Zarrugh 2014).

A beszédben észrevehető a vallásos kifejezések használata: „Ez csak akkor lehetséges, ha a tunéziai nők és férfiak jól választanak a szavazófülkékben. Ez ugyanolyan, mint amikor egy őszinte ember, aki ismeri magát, választ a bűn és a tisztaság között" (esz-Szebszi 2014). „Azért mondom, mert sok tapasztalatom van ezzel kapcsolatban, ne az embert nézzétek (rámutat a mögötte álló nőkre), hanem a programra figyeljetek, a haladás és a jólét programjára. A tunéziai kormány programjára, amely hisz a szabad, független és szuverén államban, abban, amelynek Iszlám a vallása, arab a nyelve és a köztársaság az államformája"(esz-Szebszi 2014).

A „bűn”, és a „tisztaság” kifejezések használata arra szolgál, hogy a közönség úgy érezze, minden értéket megtalálhat a Nidaa Tounés pártban. Ennek érdekében azt is érezteti, hogy a valláshoz köthető kifejezések nem csak az Ennahda párthoz tartoznak, hanem minden muszlimhoz, beleértve saját magát is. Hozzátette azt is, hogy az általa képviselt politikai államnak „iszlám a vallása”, annak érdekében, hogy tudassa a tunéziai emberekkel, a szekularizmus nem jelent egyet az ateizmussal, ahogy az ellenfeleik állítják róluk, hanem az a vallás és az állam szétválasztását jelenti. Mivel az Ennahda párt előhúzta a vallás „kártyát”, ezért esz-Szebszinek reflektálnia kellett erre, hogy tagadja az istenkáromlást, amivel vádolták. Beszédében nyilvánvalóvá tette, hogy az ország vallása az Iszlám.

Gannúsihoz hasonlóan, esz-Szebszi is a testükre hivatkozva mutatja be női támogatóit: „Nem teszek különbséget aközött a nő között, aki kendőt visel, és aközött, aki fedetlenül hagyja az arcát, mindannyian egyenlők, és mindannyiukat szívesen látjuk. Mi minden embert megvédünk, minden tunéziait, legyen az nő vagy férfi, vagy legyen más az életstílusa, mi megvédjük őket, biztosítjuk nekik, hogy szabadon élhessenek a hazájukban, szabadon és boldogan az életükben. Ahogy Bourgiba mondta: Ha isten is úgy akarja, segíteni fog nekünk megragadni a kormánykereket"(esz-Szebszi 2014).

Rasid Gannúsi a „kendő nélküli nő” kifejezést használta, hogy meggyőzze az embereket arról, hogy a pártja nem akarja elvenni a nők eddig megszerezett jogait. Ezzel szemben, esz-Szebszi, a „kendőt viselő nő” képét használja a beszédében, hogy megmutassa a pártja nem fogja elnyomni a vallást, és a kendőt viselő nőket, úgy ahogy az a Burgiba és Ben Ali rezsim alatt történt.

${ }^{19}$ Az Alkotmány 28. cikkelyére történik itt utalás. 


\section{KÖZELKÉP}

A beszéd egy másik részében a párton belüli női reprezentáció kérdésről beszélt, és kijelentette: „a kiválasztottak hozzáértő személyek”, majd hozzátette: „Azt szerettem volna, ha több nő szerepel a választási listák élén. Őszintén mondom, ez nem volt lehetséges, nagy erőfeszítéssel dolgoztam végig, és az eredmény épp itt áll előttem (a közönségre mutat), de nem volt lehetséges, bocsássanak meg nekem, de lehetetlen volt" (esz-Szebszi 2014). Elismeri, hogy a vezető, és párttag férfiak száma meghaladja a pártlistán szereplő nőkét, de nem ad meggyőző választ arra, hogy mi az oka, csak azt ismételgeti, hogy 'nem volt lehetséges'. Ennek a kijelentésnek az egyik értelmezési lehetősége az, miszerint rejtett módon azt mondja: csak a kompetens nők kerültek a listára. Ezt az értelmezést igazolja az is, hogy bár szerette volna ha több nő kerül a listára, de ez „nem volt lehetséges”, mely szövegösszefüggés közvetlenül „a kiválasztottak hozzáértő személyek” mondat után kerül hangsúlyozásra. Ebből az következik, hogy véleménye szerint nincs elég kompetens nő a pozíciók betöltésére. Később arra kérte a közönséget bízzanak abban, hogy a jövőben több nő fog magas pozíciókba jutni a különböző intézményeken belül.

Ahogy már korábban is említettem, a Nidaa Tounés párt stratégiája az Ennahda elleni egységes fellépés, és a választás megnyerése érdekében az volt, hogy a politikai hátterüktől függetlenül, minél több választót szerezzenek. Ehhez kapcsolódóan így fogalmazott: azért Nidaa Tounés a nevünk, mert ez minden tunéziai pártja. A mozgalom megalakulásakor nagyon sok szövetségesünk volt: „unionisták, destoriánusok, baloldaliak, és független tagok. Eleinte megmondták nekünk, mit hogyan kéne csinálnunk, és mi hallgattuk rájuk, így jöhetett létre ez az egység." (esz-Szebszi 2014) Látható tehát, hogy a Nidaa Tounés párt vezetője is egy széleskörü összefogás és befogadás képzetét kívánja kelteni, és erre építi politikai stratégiáját.

\section{Következtetések és elemzés}

Az elemezett szövegek és a kontextus alapján, az alábbi következtetésekre jutottunk: mindkét párt, és annak képviselői is, maszkulin hatalmi pozícióból beszélnek, ahonnan felhatalmazottnak érzik magukat arra, hogy meghatározzák a „nőkérdés” tartalmát, ezzel körülhatárolva a nők mozgásterét a politikai színtéren. Mindkét párt, bár eltérő módon, a férfiközpontú hatalmi stratégiái megvalósításának érdekében felhasználja a „nőkérdést”, ezáltal instrumentalizálja a nőket - a beszédek elhangzása idején és helyén kvázi díszletként használva őket. A vizsgált diskurzusok azt mutatják, hogy a nők komplex társadalmi helyzetének csak egy-egy aspektusa jelenik meg, kizárólag az, amely az adott politikai párt szerint maximalizálhatja a szavazatszámot, azaz a nők tárgyiasítása és instrumentalizálása politikai haszonszerzés céljából történik, a „nőkérdés” maga pedig lényegében kiüresedik.

Figyelemre méltó, hogy a beszédekben mindkét fó politikai párt (mint társadalmi aktor) vezetője utalt az arab-iszlám identitásra. Különböző stratégiákat alkalmaztak 


\section{KÖZELKÉP}

annak érdekében, hogy saját szájízük szerint láttassák a társadalmi folyamatokat és struktúrát. Mindeközben különféle meggyőzési technikákat alkalmaztak. Amíg Gannúsi, a Karl Sornig (1989) által „elítélésnek” nevezett módszert alkalmazta, mely meggyőzési technika „„óként a kognitív érveken alapul”, addig Bedzsi Kaid esz-Szebszi keverte az „elítélés” technikáját az „elcsábításon” alapuló meggyőzési móddal. Az „elcsábító meggyőzés” különbözik az „elítélés” alapútól, hiszen a beszélő erősen támaszkodik a mimikára, a mozgásra, és a hízelgésre annak érdekében, hogy meggyőzze a közönséget. Bedzsi Kaid esz-Szebszi a csábítás és az elítélés technikája között ingadozott: az „elcsábító meggyőzés” tisztán megmutatkozik abban, ahogy viccelődik és hízeleg a közönségnek. Ehhez kapcsolódóan Sornig úgy fogalmazott, hogy „az elcsábító meggyőzés célja, hogy befolyásolja a fennálló, vagy éppen elnyert kapcsolatot a beszélő és a hallgató között" (Sornig 1989, 97). Ennek érdekében mindkét vezető érzelmekkel telített diskurzusokat használt.

A diskurzust mindkét politikai párt eszközként használta az emberek figyelmének elnyerése érdekében, amelynek végső célja a hatalom megszerzése volt. Valójában mindkét egymással szemben álló párt - Bourdieu által használt fogalommal - az „erőszak puha (szimbolikus) formáit” alkalmazta. Ezek úgy teremtenek társadalmi dominancia viszonyokat, hogy közben nem alkalmaznak kényszert. A szimbolikus erőszakról tárgyalva Zizek (2008) kifejti, hogy az magában a nyelv jelöléseiben található, abban, ahogyan egymással beszélgetünk, vagy a másikról beszélünk, megteremtve és fenntartva az uralmi viszonyokat. A nőkről való beszéd mindkét politikus szövegében megteremti az uralmi viszonyokat, hiszen a hatalmat gyakorló, aktív férfi beszél, a passzívan jelenlévő nőről, akit kendővel takartan vagy anélkül konstruál meg, politikai szükségleteinek függvényében.

Az egyének, csoportok, (nyelvi) gyakorlatok és a tárgyak mezőkbe rendeződnek, ezért csak úgy érthetjük meg őket, és egymáshoz való viszonyaikat, ha a mezők alapján gondolkodunk (Sayer 2018). A tunéziai politikai mezőben, a két ellentétes párt ugyan más módokon használta fel a „nőkérdést”, azonban mindketten tárgyiasították diskurzusaikban a nőket. Az Ennahda párt a „nők, mint áldozatok” képet használta, hogy elnyerje a szavazók szimpátiáját. A párt vezetője beszédében a „kendőt nem viselő", szekuláris nő szimbolikus figuráját jeleníti meg, annak érdekében, hogy bizonyítsa pártjának befogadó irányultságát, és azt, hogy valóban a mérsékelt Iszlám irányvonalhoz tartozik, mivel a párttagsághoz nem kötelező a kendő viselete. Ezzel azt a látszatot akarta kelteni, hogy a nők szabadon választhatnak e kérdésben. Ugyanakkor, a szöveg belső ellentmondást tartalmaz, hiszen ezzel szöges ellentétben van a Saría jog bevezetésének javaslata, amely a fentivel ellentétesen konstruálja meg a nő helyét és szerepét a társadalomban és nem enged választást a nők számára.

A Nidaa Tounées, amely modern és szekuláris pártként állítja be magát, diskurzusában ugyanúgy felhasználta a nőket a több szavazat megszerzése érdekében. A párt vezetője - szemben a másik párttal - egy „kendőt viselő párttag” szimbólummá emelt nő alakját mutatja fel, annak érdekében, hogy meggyőze az embereket arról, 


\section{KÖZELKÉP}

szakítottak a Ben Ali és Burgiba rezsim alatti vallásüldözéssel, és a kendőt viselők elnyomása nem fog megismétlődni. Egyértelművé vált, hogy mindkét politikai párt a nők testét - legyen az eltakart, vagy fedetlen - használta, a hatalomért folytatott versenyben. Míg a kendőt, illetve annak hiányát az ellentétes oldalakon a befogadás és a pluralista viszonyulás szimbólumaivá emelték, a nőket változatlanul saját hatalmi játszmáik eszközeinek tekintették. Mindeközben megkonstruálták a vallásos és szekuláris nő esszencialista imázsát, akinek egyetlen számukra releváns és használható aspektusa a kendő szimbolikájában megjelenő valláshoz való viszonya.

\section{Irodalom}

Abeladhim C. (1984): Ibn Quaem Eljawzia: His era, his methodology, his thoughts in Fiqh, beliefs and Sufism. Kuwait: Dar Elkalam.

Ayman H. (2011): Rachid Ghannouchi speech, October 2011, Elkram. Tunisia. (Fordító: Nawel Ghali) https://www.youtube.com/watch?v=5kE-kkqkOKc (Letöltés: 2018. 12.09.)

Bourdieu P. (2009): A gyakorlat elméletének vázlata - Három Kabil etnológiai tanulmány Budapest: Napvilág.

Brechnmacher S. - Hubbard, C. (2020): Breaking the Cycle of Gender Exclusion in Political Party Development. Massachusetts: Carnegie Endowment for International Peace and National Democratic Institute for International Affairs (NDI).

Cavatorta F. - Merone F. (2013): Moderation through exclusion? The journey of the Tunisian EnEnnahda from fundamentalist to conservative party. Democratization, 20(5): 857-875. https://biblio.ugent.be/publication/7037446/file/ 7037448.pdf

Charrad M. (2001): States and Women's Rights: The Making of Postcolonial Tunisia, Algeria and Morocco. Berkeley, CA: University of California Press.

Charrad M. - Zarrugh, A. (2014): Equal or complementary? Women in the new Tunisian Constitution after the Arab Spring. Texas: The Journal of North African Studies, 19(2): 230-243.

Foucault M. (1972): The Archaeology of Knowledge. Tavistock Publications

Foucault M. (1998): A diskurzus rendje. In: A fantasztikus könyvtár Budapest: Pallas Stúdió 50-75.

Gill R. (2000): Discourse Analysis. In: Bouer M and Gaskell G (eds.): Qualitative researching with text image and sound: a practical handbook. London: Sage.

Grami A. (2018): Women, Feminism and Politics in Post-Revolution Tunisia: Framings, Accountability and Agency on Shifting Grounds. Feminist Dissent, (3): 23-56. https://journals.warwick.ac.uk/index.php/feministdissent/index 


\section{KÖZELKÉP}

Kammoun R. (2015): Gender and political discourse in Tunisia. In: Wilson J and Boxer D. (eds.): Discourse, Politics and Women as Global Leaders. Amsterdam, Philadelphia: John Benjamins Publishing Company, 121-148.

Kövér, Á. (2015): Fragmented discourses about women in the Hungarian public scene. In: Krasztev, P. - Van Til, J. (eds): Hungarian Patient, CEU Press Budapest, 111-132.

Louden S. (2015): Political Islamism in Tunisia: A history of Repression and a Complex Forum for Potential Change. Journal of Islamic and Middle Eastern Multidisciplinary Studies, 4(1). http://ir.uiowa.edu/mathal/vol4/iss1/2/

Mighahed N. - Lack S. (2013): Women rights and gender-educational inequality in Egypt and Tunisia. In: Napier DP and Majhanovich S (eds.): Education, Dominance, and Identity. Istanbul: Sense Publisher, 201-221.

Mills S. (1997): Discourse. London and New York: Routledge.

Nida TV, Nawel Ghali (transcription and translation) Beji Caid Essebsi's speech, October 2014, Nabeul, Tunisia. https://www.youtube.com/watch?v=1wLPGPYNcBk

Pető, A. - Kováts, E. (2017): Anti-Gender Movements in Hungary. A Discourse without a movement? In: Kuhar, R. - Paternotte. D. (eds.): Anti-Gender Campaign in Europe. 117-131.

Preysing D. (2016): Transitional Justice in Post-Revolutionary Tunisia (2011-2013). Berlin: Springer VS.

Sornig K. (1989): Some remarks on linguistic strategies of persuasion. In: Wodak $\mathrm{R}$ (ed.): Language, power and ideology, study in political discourse. Amsterdam, Philadelphia: John Benjamins Publishing Company, 92-113.

Sayer A. (2018): Bourdieu: ally or foe of discourse analysis? In: Wodak R and Forchtner B. (eds). Handbook on Language and Politics, London: Routledge, 109121.

Tuniscope (2011): Sauad Abderrahim intervention in Monte Carlo Radio, 2011. https://www.tuniscope.com/web-tv (Letöltve: 2019. 01. 19.)

Verdier M. (2013): Abou Yaareb Marzouki, l'«Islamiste moderne» Tunisien. La Croix: https://www.la-croix.com/Actualite/Monde/Abou-Yaareb-Marzouki-lislamiste-moderne-tunisien-2013-10-23-1049739 (Letöltve: 2019. 01. 29.)

Vogel, L. (1995): Woman questions: Essay for a materialist feminism. New York: Routledge

Wodak R. (1997): Introduction: Some important issues in the research of gender and discourse. In: Wodak R. (ed.): Gender and discourse. London, Thousand Oaks, New Delhi: Sage Publications, 1-20. 


\section{KÖZELKÉP}

Wodak R. (ed.) (1989): Language, power and ideology, study in political discourse. Amsterdam, Philadelphia: John Benjamins Publishing Company.

Wolf A. (2017): Political Islam in Tunisia: The History of EnEnnahda. New York: Oxford University Press.

Zayani M. (2015): Networked Publics and Digital Contention: The Politics of Everyday Life in Tunisia. Oxford University Press.

Zeghal M. (2013): Competing Ways of Life: Islamism, Secularism, and Public Order in the Tunisian Transition. Constellations, 20(2): 254-274. https://onlinelibrary. wiley.com/doi/epdf/10.1111/cons.12038

Zizek S. (2008): Violence. Picador, New York. 